\title{
The Relationship Between Social Support and Psychological Well-Being of College Students during COVID-19 Pandemic
}

\author{
Nadatuljannah Alza ${ }^{1}$, Rani Armalita ${ }^{1 *}$, Dwi Puspasari ${ }^{1}$ \\ ${ }^{1}$ Universitas Andalas, Indonesia \\ *Corresponding author, e-mail: raniarmalita@med.unand.ac.id
}

\begin{abstract}
One of those affected by the COVID-19 pandemic is college students. It made the learning process that was previously carried out face-to-face became online. This condition affects the psychological well-being of college students. One of the factors that influence psychological well-being is social support. The goal of this research is to investigate the relationship between social support and the psychological well-being of college students during the COVID-19 pandemic. The method used in this research was a quantitative method with a correlational design. A total of 351 college students who attend lectures during the COVID-19 pandemic and studied in the city of Padang, West Sumatra, Indonesia became a subject of this research. Measurement was carried out by adapting the scale and each scale has a reliability of .795 and .894 . The results showed that social support was significantly related to the psychological well-being of college students during the COVID-19 pandemic which could be seen from the significance value of $.00(p<.05)$. The Pearson correlation value in the research was .668, this indicates that the relationship between social support and the psychological well-being of college students during the COVID-19 pandemic is in a strong category.
\end{abstract}

Keywords: Social Support, Psychological Well-Being, College student, COVID-19 Pandemic

How to Cite: Alza, N., Armalita, R., \& Puspasari, D. (2021). The Relationship Between Social Support and Psychological Well-being of College Students during COVID-19 Pandemic. International Journal of Research in Counseling and Education, VV (N): pp. 79-84, DOI: https://doi.org/10.240$\underline{36 / 00445 z a 0002}$

\section{Introduction}

The Coronavirus Disease 2019 (COVID-19) epidemic first broke out in China in December 2019 and has spread almost all over the world (Cao, Fang, Hou, Han, Xu, Dong, \& Zheng., 2020). With this spread, COVID-19 was declared a global pandemic by the World Health Organization (WHO) on March 11, 2020 (Tee, Tee, Anlacan, Aligam, Reyes, Kuruchittham, \& Ho., 2020). The continued spread has prompted the government to issue Government Regulation Number 21 of 2020 concerning Large-Scale Social Restrictions (PSBB) in the Context of Accelerating Handling of Corona Virus Disease 2019 (COVID-19). Then, the Minister of Education and Culture of the Republic of Indonesia also issued Circular Letter Number 4 of 2020 concerning the Implementation of Education Policies in the Emergency Period for the Spread of COVID-19. In addition to regulations and circulars, there is also an appeal from the government for social distancing and physical distancing in order to prevent the spread of COVID-19 (Kompas.TV, 2020).

One of those affected by the regulations, circulars, and appeals are college students, where the learning process that is usually done face-to-face has turned online during the COVID-19 pandemic. This condition affects psychological well-being which then has an impact on the mental health of college students. Several studies have shown that the COVID-19 pandemic poses mental health problems for college students (Jiang, 2020; Li, Zhao, Ma, McReynolds, Lin, Chen, Wang, Wang, Zhang, Zhang, Fan, Liu., 2021; Savage, James, Magistro, Donaldson, Healy, Nevill, \& Hennis., 2020). According to Zubayer, Rahman, Islam, Babu, Rahman, Bhuiyan, Khan, Chowdhurry, Hossain, \& Habib (2020) this is due to the continued spread of the virus and the enactment of restrictive regulations related to the pandemic. Based on the YoungMinds (2020) survey, $83 \%$ of respondents think that their existing condition has become worse due to the suspension of educational activities along with the loss of routine and social relationships. The results of the research by Meo, 
Abukhalaf, Alomar, Sattar, \& Klonoff (2020) show that college students feel emotionally separated from their family and friends and there is a decrease in their overall work performance and study period.

According to Ryff (1989) psychological well-being is a term used to describe individual psychological health based on the fulfillment of positive psychological functioning criteria. Good psychological well-being is characterized by the fulfillment of all existing dimensions. Someone who has high psychological well-being will feel comfortable, capable, happy, well supported, satisfied with life and can carry out his function as a positive human being (Noviasari \& Dariyo, 2016; Winefield, Gill, Taylor, \& Pilkington., 2012).

One of the factors that influence psychological well-being is social support (Liwarti, 2013). Social support according to Cutrona \& Russell (1987) is a process of emotional maintenance, building self-esteem, providing feedback, and real assistance to individuals who are experiencing problems or pressures in life. The results of research conducted by Fransisca (2018); Kurniawan \& Eva (2020); Rachmadhani (2020), found that there was a positive relationship between social support and psychological well-being in overseas college students. When the social support obtained is higher, the psychological well-being of overseas college students is also higher. Vice versa, when the social support obtained is getting lower, the psychological well-being of overseas college students will also be lower.

During the COVID-19 pandemic, social support is needed. This is because COVID-19 has a high prevalence of symptoms of depression and anxiety. The results of the research by Qi, Zhou, Guo, Zhang, Min, Li, \& Chen (2020) found that low and moderate social support was associated with a high prevalence of symptoms of depression and anxiety. Then the results of Ye, Yang, Zeng, Wang, Shen, Li, \& Lin (2020) research found that social support can be one of the factors that reduce the risk of experiencing stress related to COVID-19. Wang, Cai, Qian, \& Peng (2014) also found that the presence of good social support can provide problem solving strategies to individuals and reduce the harmful effects of stressful experiences. So that the existence of social support will help individuals to reduce the prevalence of depression and anxiety.

Based on the explanation above, it was found that the provision of social support was related to the psychological well-being of college students. However, so far, researchers have not seen any research that discusses the relationship between social support and psychological well-being of college students during the COVID-19 pandemic. So that researchers are interested in conducting research on the relationship between social support and psychological well-being of college students during the COVID-19 pandemic. The hypothesis of this research is that there is a significant relationship between social support and psychological well-being of college students during the COVID-19 pandemic.

\section{Method}

The population in this research were college students who took online lectures during the COVID-19 pandemic. 351 college students who took online lectures during the COVID-19 pandemic and studied in the city of Padang, West Sumatra, Indonesia became a subject of this research. From 351 subjects in this research, 118 college students (33.6\%) came from Universitas Andalas, 116 college students (33.0\%) came from Universitas Bung Hatta, 63 college students (17.9\%) came from Universitas Negeri Padang, 39 college students (11.1\%) came from STKIP PGRI Sumatera Barat, 13 college students (3.7\%) came from UIN Imam Bonjol, 1 college student $(0.3 \%)$ came from Universitas Eka Sakti and 1 college student $(0.3 \%)$ from Universitas Perintis Indonesia. The sampling technique used in this research is purposive sampling. In this research, psychological well-being is measured by adapting the Scale of Psychological Well-Being Scale (SPWB) by Ryff which has been modified by Vinandityo (2012). The reliability of this measuring instrument is .795. To measure social support, the researcher adapted the Social Provisions Scale by Cutrona \& Russell (1987). The reliability of this measuring instrument is .894 . The method used in this research is a quantitative method with a correlational design. The analysis used in this research is product moment correlation analysis.

\section{Results}

The results of the descriptive analysis of student social support during the COVID-19 pandemic are:

Table 1: Results of Descriptive Analysis of Social Support

\begin{tabular}{llll}
\hline Categorization & Range Value & Total & Percentage \\
\hline High & $\mathrm{X} \geq 57.5$ & 306 & $87,2 \%$ \\
Low & $\mathrm{X}<57.5$ & 45 & $12,8 \%$ \\
Total & & 351 & $100 \%$ \\
\hline
\end{tabular}


Based on the results of the descriptive analysis of social support above, it was found that in this research 306 college students (87.2\%) had high social support. This can be interpreted that the college students during the COVID-19 pandemic have received support such as attention, information, feedback, and real assistance from their social environment. Then as many as 45 college students (12.8\%) had low social support, meaning that during the COVID-19 pandemic they did not get support such as attention, information, feedback and real assistance from their social environment.

Furthermore, the results of the descriptive analysis of the psychological well-being of college students during the COVID-19 pandemic are:

Table 2. Results of Psychological Well-Being Descriptive Analysis

\begin{tabular}{llll}
\hline Categorization & Range Value & Total & Percentage \\
\hline High & $\mathrm{X} \geq 56$ & 337 & $96 \%$ \\
Low & $\mathrm{X}<56$ & 14 & $4 \%$ \\
Total & & 351 & $100 \%$ \\
\hline
\end{tabular}

Based on the results of descriptive analysis of psychological well-being variables, it was found that in this research 337 college students (96\%) had high psychological well-being. This can be interpreted that the college student during the COVID-19 pandemic can live a good life. This is characterized by their having a purpose in life, autonomy, being able to develop their potential, being able to master the environment, having positive relationships with others, and having positive self-acceptance. Then as many as 14 respondents (4\%) have low psychological well-being. This means that during the COVID-19 pandemic, these college students cannot live a good life. This is characterized by they have no purpose in life, do not have self-autonomy, cannot develop their potential, are unable to master the environment, do not have positive relationships with others, and do not have positive self-acceptance.

Table 3. Mean score of social support dimension

\begin{tabular}{ll}
\hline Dimension & Mean \\
\hline Reassurance of worth & 3.00 \\
Social Integration & 3.02 \\
Opportunity of nurturance & 3.08 \\
Reliable alliance & 3.08 \\
Guidance & 3.14 \\
Attachment & 3.15 \\
\hline
\end{tabular}

In this research, the reassurance of worth dimension is the dimension with the lowest mean among other dimensions. It means that they have received support from their social environment but they still need recognition of the competencies, skills, and values possessed by their social environment. Then, the attachment dimension is the dimension with the highest mean value among other dimensions. It means they have received support from the social environment, especially getting emotional closeness with their social environment so that they have a sense of security.

Table 4. Mean score of psychological well-being dimension

\begin{tabular}{lc}
\hline \multicolumn{1}{c}{ Dimension } & Mean \\
\hline Positive relationship with others & 4.08 \\
Environment mastery & 4.13 \\
Self-acceptance & 4.24 \\
Autonomy & 4.67 \\
Personal growth & 5.23 \\
Purpose in life & 5.37 \\
\hline
\end{tabular}

In this research, the dimension of positive relationships with other people is the dimension with the lowest average among the other dimensions. It means they have s few close and trusting relationships with others; finds it difficult to be warm, open, concerned about others; isolated and frustrated in interpersonal relationships; not willing to make compromises to sustain important ties with others. Then, the dimension of purpose in life is the dimension with the highest mean among other dimensions. It means they have goals in 
life and a sense of directedness; feels there is meaning to present and past life; holds beliefs that give life purpose; has aims and objectives for living.

Based on the mean score of the two variables above, the researcher found that dimension positive relationship with others is the lowest meanwhile dimension attachment is the highest score. It means even though they have few closes and trusting relationships with others, but they are emotionally close and feel safe with their relationship. As we all know, the COVID-19 pandemic has hit our lives so hard. We find some difficulties during the COVID-19 pandemic. So, with the attachment they get from the social environment it helps them survive during the COVID-19 pandemic.

The results of the correlation test between the two variables can be seen in the following table:

Table 5. Correlation Test Results

\begin{tabular}{cccc}
\hline Variabel & Sig & Pearson Correlation & Explanation \\
\hline Psychological Well-Being - Social Support & .000 & .668 & Significant \\
\hline
\end{tabular}

\section{Discussion}

Based on the table 1 above, it can be seen that the significance value of the relationship between psychological well-being and social support is less than $.05(\mathrm{p}<.05)$. Its means, there is a relationship between psychological well-being and social support. The correlation between the two variables is a positive correlation, which means that the higher the social support, the higher the psychological well-being of college students.

The results of this research are in line with the results of research conducted by Fransisca (2018); Kurniawan \& Eva (2020); Rachmadhani (2020), who found that there was a positive relationship between social support and psychological well-being in overseas college students. When the social support obtained is higher, the psychological well-being of overseas college students will also be higher. Vice versa, when the social support obtained is getting lower, the psychological well-being of overseas college students will also be low. This result is also in line with the results of research conducted by Fitria (2019) on working college students, namely the higher the social support, the higher the psychological well-being of working college students and the lower the social support, the lower the psychological well-being of college students who work.

During the COVID-19 pandemic, social support is needed. Social support can come from many sources, including spouse or lover, family, friends, or community organizations. This is because COVID-19 has a high prevalence of symptoms of depression and anxiety. Ye, et al (2020) found that social support can be one of the factors that reduce the risk of experiencing stress related to COVID-19. According to Wang, et al (2014) good social support can provide problem solving strategies to individuals and reduce the harmful effects of stressful experiences. This is also in line with Thoits (2011) with social support helping individuals see situations in a different way, suggesting ways to solve problems, and encouraging individuals to vent their feelings.

When individuals get social support in the form of assistance in seeing situations in a different way, getting advice in solving problems, and being able to express their feelings, it will affect the psychological well-being of the individual. This is indicated by them feeling comfortable and feeling well supported. This is in line with Santoso's opinion (2020) with support it will help reduce stress and depression which then has an impact on psychological well-being because they feel comfortable and safe. This condition will affect their survival. As stated by Eva, Shanti, Hidayah, \& Basri (2020) that psychological well-being can be a predictor for individuals in various aspects such as personal-social, academic, and career.

Last, based on the results of the research the researcher proposes several suggestions that can be used, namely for further researchers who are interested in similar research themes, they can conduct research with different research designs, such as causality correlation designs. In order to be able to see how much influence social support has on the psychological well-being of college students during the COVID-19 pandemic. Then, for future researchers who are interested in similar research themes, they can focus their research on one source of social support, such as only parents or peers. In order to be more specifically seen how the relationship between the two variables. 


\section{Conclusion}

Based on the results of the research and hypothesis testing that have been carried out, the conclusion is that there is a significant relationship between social support and the psychological well-being of college students during the pandemic COVID-19. Thus, the higher the social support received by college students, the higher the psychological well-being of college students during the COVID-19 pandemic. On the other hand, the lower the social support received by college students, the lower the psychological well-being of college students during the COVID-19 pandemic. In this research, it was found that most of the subjects in this study have high psychological well-being and social support.

\section{References}

Cao, W., Fang, Z., Hou, G., Han, M., Xu, X., Dong, J., \& Zheng, J. (2020). The Psychological Impact of The COVID19 Epidemic on College Students in China. Psychiatry Research, 287March), 112934. https://doi.org/10.1016/j.psychres.2020.112934

Cutrona, C. E., \& Russell, D. W. (1987). The provisions of social relationships and adaptation to stress. Advances in Personal Relationship, 1(January), 37-67.

Eva, N., Shanti, P., Hidayah, N., \& Bisri, M. (2020). Pengaruh dukungan sosial terhadap kesejahteraan psikologis mahasiswa dengan religiusitas sebagai moderator. Jurnal Kajian Bimbingan Dan Konseling, 5(3), 122-131. https://doi.org/10.17977/um001v5i32020p122

Fitria, S. (2019). Hubungan dukungan sosial dengan psychological well-being pada mahasiswa sambil bekerja. UIN Sunan Gunung Djati.

Fransisca, N. (2018). Hubungan antara dukungan sosial dengan psychological well-being pada mahasiswa perantau di Universitas Katolik Soegijapranata Semarang. Universitas Katolik Soegijapranata.

Jiang, R. (2020). Knowledge, attitudes and mental health of university students during the COVID-19 pandemic in China. Children and Youth Services Review, 119, 105494. https://doi.org/10.1016/j.childyouth.2020.105494

Kompas.TV. (2020). Jokowi: Social Distancing, Physical Distancing, Itu yang Paling Penting. https://www.kompas.tv/article/74309/jokowi-social-distancing-physical-distancing-itu-yang-palingpenting

Kurniawan, S. R., \& Eva, N. (2020). Hubungan antara dukungan sosial dengan kesejahteraan psikologis pada mahasiswa rantau. Prosiding Seminar Nasional Dan Call Paper "Psikologi Positif Menuju Mental Wellness," 152-162.

Li, Y., Zhao, J., Ma, Z., McReynolds, L. S., Lin, D., Chen, Z., Wang, T., Wang, D., Zhang, Y., Zhang, J., Fan, F., \& Liu, X. (2020). Mental Health Among College Students During the COVID-19 Pandemic in China: A 2-Wave Longitudinal Survey. Journal of Affective Disorders. https://doi.org/10.1016/j.jad.2020.11.109

Liwarti. (2013). Hubungan pengalaman spiritual dengan sychological well being pada penghuni lembaga pemasyarakatan. Jurnal Sains Dan Praktik Psikologi, 11), 77-88.

Meo, S. A., Abukhalaf, A. A., Alomar, A. A., Sattar, K., \& Klonoff, D. C. (2020). COVID-19 Pandemic: Impact of Quarantine on Medical Student's Mental Wellbeing and Learning Behaviors. Pakistan Journal of Medical Sciences, 36(COVID19-S4), S43-S48. https://doi.org/10.12669/pjms.36.COVID19-S4.2809

Noviasari, N., \& Dariyo, A. (2016). Hubungan psychological well-being dengan penyesuaian diri pada istri yang tinggal di rumah mertua. Psikodimensia, 15(1), 134-151. http://journal.unika.ac.id/index.php/psi/article/view/596

Qi, M., Zhou, S. J., Guo, Z. C., Zhang, L. G., Min, H. J., Li, X. M., \& Chen, J. X. (2020). The effect of social support on mental health in chinese adolescents during the outbreak of COVID-19. Journal of Adolescent Health, 674), 514-518. https://doi.org/10.1016/j.jadohealth.2020.07.001

Rachmadhani, M. P. (2020). Hubungan antara dukungan sosial dengan psychological well-being pada mahasiswa rantau di Universitas Airlangga Surabaya. Universitas Airlangga.

Ryff, C. D. (1989). Happiness is everything, or is it? Explorations on the meaning of psychological well-being. Journal of Personality and Social Psychology, 576), 1069-1081. https://doi.org/10.1037/00223514.57.6.1069

Santoso, M. D. Y. (2020). Review Article: Dukungan Sosial Dalam Situasi Pandemi Covid 19. Jurnal Litbang Sukowati: Media Penelitian Dan Pengembangan, 5(1), 11-26. https://doi.org/10.32630/sukowati.v5i1.184

Savage, M. J., James, R., Magistro, D., Donaldson, J., Healy, L. C., Nevill, M., \& Hennis, P. J. (2020). Mental Health 
and Movement Behaviour During The COVID-19 Pandemic in UK University Students: Prospective Cohort Study. Mental Health and Physical Activity, 19, 100357. https://doi.org/10.1016/j.mhpa.2020.100357

Tee, M. L., Tee, C. A., Anlacan, J. P., Aligam, K. J. G., Reyes, P. W. C., Kuruchittham, V., \& Ho, R. C. (2020). Psychological Impact of COVID-19 Pandemic in The Philippines. Journal of Affective Disorders, 277August), 379-391. https://doi.org/10.1016/j.jad.2020.08.043

Thoits, P. A. (2011). Mechanisms linking social ties and support to physical and mental health. Journal of Health and Social Behavior, 52(2), 145-161. https://doi.org/10.1177/0022146510395592

Vinandityo, B. (2012). Hubungan Everyday Creativity dan Psychological Well-being: Sebuah Studi Pada Mahasiswa Universitas Indonesia.

Wang, X., Cai, L., Qian, J., \& Peng, J. (2014). Social Support Moderates Stress Effects on Depression. International Journal of Mental Health Systems, 8(14), 1-5. https://doi.org/10.1186/1752-4458-8-41

Winefield, H. R., Gill, T. K., Taylor, A. W., \& Pilkington, R. M. (2012). Psychological Well-Being and Psychological Distress: Is It Necessary to Ieasure Both? Psychology of Well-Being: Theory, Research and Practice, 2, 1-14. https://doi.org/10.1186/2211-1522-2-3

Ye, Z., Yang, X., Zeng, C., Wang, Y., Shen, Z., Li, X., \& Lin, D. (2020). Resilience, social support, and coping as mediators between COVID-19-related stressful experiences and acute stress disorder among college students in China. Applied Psychology: Health and Well-Being. https://doi.org/10.1111/aphw.12211

YoungMinds. (2020). Coronavirus: Impact on Young People with Mental Health Needs.

Zubayer, A. Al, Rahman, M. E., Islam, M. B., Babu, S. Z. D., Rahman, Q. M., Bhuiyan, M. R. A. M., Khan, M. K. A., Chowdhury, M. A. U., Hossain, L., \& Habib, R. Bin. (2020). Psychological states of Bangladeshi people four months after the COVID-19 pandemic: An online survey. Heliyon, 6, 1-6. https://doi.org/10.1016/j.heliyon.2020.e05057 